\title{
12
}

\section{Litigating the Crisis: Towards a Rebalancing of the Rights of Investors Versus Public Interest?}

\author{
Morag Goodwin and Phillip Paiement
}

This chapter reflects on the anticipated rush by private corporations to seek compensation from states for emergency measures taken to address the current health crisis. Where states have, for example, commandeered privately run health facilities, foreign corporations can claim for any negative impact on their current and future profits. This anticipated wave of state-investor litigation draws upon the web of bilateral investment treaties that span the globe and on Investor-State Dispute Settlement (ISDS) mechanisms. In place of a "new normal," this short paper suggests that these threats represent an intensification of an existing trend, with the main difference being that states of the Global North are increasingly finding themselves disciplined by instruments that they created to protect their own companies abroad. If this happens, as seems likely, this crisis will add to the growing calls to rethink how we regulate the boundary between the public interest and private investors.

At the heart of this type of transnational litigation is a dispute about the relationship between notions of public and private and the definition of "public interest" that acts as a check on the freedom of action of both states and private actors. The legal basis is the system of Investor-State Dispute Settlement

\section{Goodwin $(\bowtie) \bullet$ P. Paiement}

Department of Public Law and Governance, Tilburg Law School,

Tilburg, The Netherlands

e-mail: M.E.A.Goodwin@tilburguniversity.edu; P.M.Paiement@tilburguniversity. edu

E. Aarts et al. (eds.), The New Common, https://doi.org/10.1007/978-3-030-65355-2_12 
and the complex web of bilateral investment treaties (BITs) and the occasional multilateral trade treaty that constitute the rules of interaction between foreign corporations and investors and the public authorities that host the investment. The system is part of international law and is therefore governed by its general rules. The basic principle of the system is that states protect the interests of companies and investors incorporated in their state when those companies and investors act abroad, by laying down shared—bilateral—rules that prohibit discriminatory action, such as expropriation.

There are many $1000 \mathrm{~s}$ of BITs currently in operation, most of which were drafted in the 1980s and 1990s. What gives these treaties their bite are the provisions they contain that exclude the domestic courts of the host state from any role in regulating disputes between investors and the state in favor of international arbitration. Yet while BITs are-as the name suggests-a bilateral agreement between two states, it has increasingly been recognized that they are, in practice, unbalanced, and are unfair towards states of the Global South.

In place of a guarantee of mutual interests, BITs have worsened the power imbalance upon which they are based in favor of corporate interests over the public authorities of poorer states (Peronne 2016a, b). The practice of dispute resolution guaranteed by BITs has led to a dramatic expansion of investor rights under the notion of "indirect expropriation," which covers any measures taken by governments that have a negative impact on investment (UNCTAD 2000). These claims see host governments subjected to claims by foreign firms that frequently result in huge payouts that, in turn, have an equally huge impact on the ability of developing countries to improve public welfare. As such, it has been argued, that the ISDS system promotes the rights of Western-based corporations over those of developing states (Gallacher and Shrestha 2011). This has led to calls for a moratorium on investor-state cases within the ISDS system and a re-writing of the rules of the game (Columbia Center on Sustainable Investment 2020; Kahale III 2018).

\section{The Current Crisis}

The dramatic nature of the policy responses by governments in the face of the COVID-19 pandemic gives rise to a myriad of potential liabilities for states stemming from their obligations towards foreign investors under their international investment agreements. These liabilities concern both public health measures taken to quell the spread and health consequences of the pandemic as well as subsidiary measures taken in response to the pandemic's social and 
economic consequences, including those flowing from corresponding public health restrictions. Examples of direct public health measures that may pose harmful consequences to the undertakings of foreign investors include: the nationalization of private medical care facilities; compulsory licensing for patented drugs and medical devices; the reduction or prohibition of the exportation of medical materials; requisitioning hotels to serve as health clinics or quarantine sites; and compelling manufacturers to produce medical supplies.

In addition, the following social and economic policies intended to limit the consequences of the pandemic could also impact foreign investors in a manner that would give rise to ISDS arbitration: moratoriums on toll-roads, rent payments, and utilities payments; the introduction of limitations on contractual liabilities and other creditor protections; limitations of foreign investments to protect against buyouts of distressed assets; moratoriums on bankruptcy proceedings; suspension of mortgage payments; moratoriums on utilities connection cancelations; tax relief measures to support businesses particularly affected by the pandemic; and the prohibition of companies domiciled in tax havens from receiving financial aid. In a "damned if you do, damned if you don't" manner, states might even be exposed to liability if they fail to take sufficient measures to ensure public order. Based on the concept of indirect expropriation, such governments could face claims if looting or other social unrest affects foreign investors, as was the case in Egypt during the Arab Spring when disruptions and theft from gas pipelines led Ampal-American Israel Corporation to initiate ISDS proceedings against Egypt for $\$ 535$ million, a procedure which is still pending. It is quite possible to imagine ISDS claims arising both for a failure by governments to prevent a subsequent wave of infections due to a lifting of restrictions too quickly or because they failed to enforce restrictions sufficiently well; and because they implemented lockdown rules in the first place. Simply put, the complexity of policy responses to the pandemic presents countless opportunities for ISDS to arise.

Already in late March, while the pandemic was in its worst stages in Europe with thousands of deaths each day, attorneys from ArbLit in Milan were publicly contemplating the potential investment claims that may come out of the pandemic (Benedetteli et al. 2020). Since then, numerous law firms specialized in investment arbitration have been contacting potential clients in order to raise awareness about the types of claims that they may be able to pursue against states whose measures have impacted their businesses. 


\section{Fighting Back}

Despite it long being accepted by many scholars, countries, and international institutions that the ISDS system is detrimental to the interests of the Global South, the system perseveres. Previous government crises, such as Argentina's 15 year-long financial crisis of 1998-2002, or the Arab Spring-while they led to calls for reform-did not lead to change. Nor has the permanent governance crisis of many Global South states created sufficient momentum for a rebalancing of investors' rights in favor of the public interest. The system is not unchallenged, however. Bolivia, Ecuador, and Venezuela have all withdrawn from the International Centre for Settlement of Investment Disputes (ICSID) Convention this century (in 2007, 2009 and 2012, respectively) (Voon and Mitchell 2016). Other efforts to fight back include the termination of older generation BIT agreements: for example, Venezuela terminated its BIT with The Netherlands in 2008 after it was used as the basis for ICSID jurisdiction in 10 cases (Fach Gómez 2010), Bolivia has terminated 10 of its $23 \mathrm{BITs}$, and Indonesia has terminated 26 of its 71 BITs (Ranjan 2019).

However, the fight back is not limited to states of the Global South. In recent years, a number of wealthy countries have recognized that the system does not serve their interests either. In 2009, the Australian government requested the Productivity Commission — a governmental advisory body-to investigate the impact of Australia's bilateral and trade agreements on Australia's economic performance. Its 2010 report found no evidence that ISDS provisions increase foreign investor inflow and held that, in contrast, ISDS provisions represented "considerable policy and financial risks" to the Australian state. Its conclusion, that "the Australian government should seek to avoid the inclusion of investor state dispute settlement provisions in bilateral and regional trade agreements," led to a rethink of Australian trade policy (Productivity Commission 2010; Ranald 2011). Notably, the report immediately preceded a lengthy and costly ISDS claim filed by tobacco conglomerate Philip Morris's Hong Kong subsidiary against Australia for its 2011 tobacco plain packaging legislation, a dispute in which Australia ultimately prevailed, paving the way for similar legislation in developing countries.

Similarly, the Dutch government decided in 2018 to create a new BIT model treaty to serve as the basis for the renegotiation of all 79 BITs between the Dutch state and non-EU countries. The new model is designed to create a fairer balance by introducing stricter eligibility criteria for investors to be able to make claims against states. One significant change is that claims of indirect expropriation will now require "fundamental attributes of property" 
to be taken, which means, for example, that fluctuations in prices as a result of government measures will no longer be claimable (Marsman 2018). These changes by the Dutch government are important, as Dutch BITs are the second most invoked by investors globally, and the old model is widely viewed as offering "the gold standard" of investor protection. This change of heart by the Dutch government is prompted by recognition of the need to rebalance the rights of investors against state interests. More importantly, it follows the realization that power shifts in the global economy entail that the Netherlandstraditionally an investment-exporting country-is now primarily a capitalimporting state. For example, $36 \%$ of residential rental properties sold in the Netherlands in 2019 were purchased by foreign investors (Rachid 2019). Strict investor protection is increasingly viewed by the Dutch state as detrimental to its interests in place of protecting them (Duggal and van de Ven 2019). It is not alone amongst Northern states.

\section{Litigating This Crisis}

Should states be faced with investment arbitration in response to their COVID-19 policy measures, they have two general pathways to defend their actions (Martinez 2010). First, they can rely on the defense of necessity as developed in customary international law. However, exceptions under necessity or emergency scenarios are not usually recognized in international investment agreements, which raises the risk that an arbitration panel will not accept such a defense. Second, they may rely on regulation in the public interest exception clauses, which are increasingly common in international investment agreements, yet fairly uncommon in older agreements. This justification, if available, would be subject to proportionality testing by an arbitration panel to determine whether measures less harmful for foreign investors would have been possible. There is a fair chance that many states could successfully defend their actions in this manner. Yet the prospect of proportionality evaluations and potential massive payouts to foreign investors for government actions in a pandemic that has taken the lives of hundreds of thousands of Europeans and North Americans is likely to be deeply unpalatable to these governments and their voters. We should not anticipate that actions by corporations in response to the pandemic could lead to the development of a "new common" amongst states - competition is, after all, the beating heart of capitalism and hence of the global economy. The most that can be hoped is that the pandemic gives powerful states the incentive to initiate reforms to the 
international investment treaty system and hence continue the trend towards a rebalancing of public interest and investors' rights.

\section{References}

Benedetteli M, Coroneo C, Minella N (2020) Could COVID-19 emergency measures give rise to investment claims? First reflections from Italy, Global Arbitration Review, 26 March 2020

Columbia Center on Sustainable Investment (2020) Call for ISDS moratorium during COVID-19 crisis and response. http://ccsi.columbia.edu/2020/05/05/ isds-moratorium-during-covid-19/

Duggal KAN, van de Ven LH (2019) The 2019 Netherlands model BIT: riding the new investment treaty waves. Arbitr Int 35(3):347-374

Fach Gómez K (2010) Latin America and ICSID: David versus Goliath, Law Bus Rev Am. 17: 195. doi:https://doi.org/10.2139/ssrn.1708325

Gallacher KP, Shrestha E (2011) Investment treaty arbitration and developing countries: a re-appraisal. J World Invest Trade 12(6):1660-7112

Kahale G III (2018) The inaugural Brooklyn lecture on international business law: ISDS: the wild, wild west of international practice. Brooklyn J Int Law 44(1):1-10

Marsman A (2018) New model treaty to replace 79 existing Dutch bilateral investment treaties. De Brauw, Blackstone, Westbroek, Amsterdam. https://www.debrauw.com/legalarticles/new-model-treaty-to-replace-79-existingdutch-bilateral-investment-treaties/

Martinez A (2010) Invoking state defenses in investment treaty arbitration. In: Waibel M, Kaushal A, Chung K-H, Balchin C (eds) The backlash against investment arbitration. Kluwer Law International, Alphen aan den Rijn, pp 315-338

Peronne NM (2016a) The international investment regime and local populations: are the weakest voices unheard? Transnat Legal Theory 7(3):383-405

Peronne NM (2016b) The international investment regime after the global crisis of neoliberalism: rupture or continuity? Indiana J Global Legal Stud 23(2):603-627

Productivity Commission (2010) Bilateral and Regional Trade Agreements Final Report. Productivity Commission, Canberra. https://www.pc.gov.au/inquiries/ completed/trade-agreements/report/trade-agreements-report.pdf

Rachid M (2019) Dutch residential market enjoys new record investment in 2019, World Property Journal, 11 December 2019. https://www.worldpropertyjournal. $\mathrm{com} /$ real-estate-news/netherlands/amsterdam/real-estate-news-capital-valuenetherlands-property-transaction-data-for-2019-property-investment-data-forthe-netherlands-dutch-foreign-buyer-data-11715.php

Ranald P (2011) Investor-state dispute settlement (ISDS): the threat to health, environment and other social regulation. Presented at the Stakeholders Forum, 10 September 2011, Chicago 
Ranjan P (2019) Police Powers, Indirect Expropriation in International Investment Law, and Article 31(3)(c) of VCLT: A Critique of Philip Morris v. Uruguay. Asian J Int Law 9(1):98-124

United Nations Committee on Trade and Development (UNCTAD) (2000) Taking of property, Issues in International Investment Agreements. United Nations, New York/Geneva. https://unctad.org/en/Docs/psiteiitd15.en.pdf

Voon T, Mitchell AD (2016) Denunciation, termination and survival: the interplay of treaty law and international investment law. ICSID Rev Foreign Invest Law J 31(2):413-433

Open Access This chapter is licensed under the terms of the Creative Commons Attribution 4.0 International License (http://creativecommons.org/licenses/by/4.0/), which permits use, sharing, adaptation, distribution and reproduction in any medium or format, as long as you give appropriate credit to the original author(s) and the source, provide a link to the Creative Commons licence and indicate if changes were made.

The images or other third party material in this chapter are included in the chapter's Creative Commons licence, unless indicated otherwise in a credit line to the material. If material is not included in the chapter's Creative Commons licence and your intended use is not permitted by statutory regulation or exceeds the permitted use, you will need to obtain permission directly from the copyright holder.

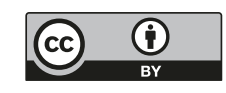

